\title{
EVALUATION CRITERIA OF SMART CITY MOBILITY SYSTEM USING MCDM METHOD
}

\author{
SIMONA ZAPOLSKYTE் ${ }^{\star *}$, MARIJA BURINSKIENÉ ${ }^{2}$ \\ MARTIN TRÉPANIER ${ }^{3}$ \\ ${ }^{1,2}$ Department of Roads, Faculty of Environmental Engineering, \\ Vilnius Gediminas Technical University, Vilnius, Lithuania \\ ${ }^{3}$ Polytechnique Montréal, Interuniversity Research Centre on Enterprise \\ Networks, Logistic and Transportation (CIRRELT), Montréal, Canada
}

Received 10 April 2020; accepted 1 July 2020

\begin{abstract}
While many cities around the world qualify themselves as "smart cities", there is no comprehensive way to evaluate to what extent they are "smart". This article proposes a framework for comparison of the level of "smartness" of the urban mobility systems. The most relevant indicators that have the greatest impact on smart mobility systems were selected in the course of literature review. The impact of indicators on smart mobility systems is variable. Evaluating smart mobility systems, different authors distinguish between different indicators, which usually do not duplicate. The paper categorizes the indicators of the smart mobility system into five groups, called "factors": motor travel and congestion reduction measures; pollution reduction measures; travel safety and accident reduction measures; traffic management tools and services; smart infrastructure measures. A number of indicators are attributed to each of the listed groups. A Multiple Criteria Decision-Making method, namely, the Analytic Hierarchy Process (AHP) method, has been used to evaluate the significance of the smartness level used in the research. This
\end{abstract}

* Corresponding author. E-mail: simona.zapolskyte@vgtu.lt

Marija BURINSKIENĖ (ORCID ID 0000-0002-6685-5840)

Martin TRÉPANIER (ORCID ID 0000-0001-8408-8035)

Copyright (C) 2020 The Author(s). Published by RTU Press

This is an Open Access article distributed under the terms of the Creative Commons Attribution License (http://creativecommons.org/licenses/by/4.0/), which permits unrestricted use,

distribution, and reproduction in any medium, provided the original author and source are credited. 
method bases the weighting of subjective criteria on expert judgement. Rank correlation is used to determine the consistency of expert opinions. A model has been developed to compare smart mobility systems of individual cities and their infrastructure.

Keywords: benchmarking, intelligent infrastructure, multicriteria analysis, smart city mobility system, smartness index.

\section{Introduction}

Rapid urban population growth has a negative impact on urban mobility systems. It has brought the need to address the problems of improving transport services and increasing demand for public transport. However, increase in transport supply is often accompanied by undesirable results. Cities are facing challenges such as traffic jams, rising property prices, environmental pollution, overpopulation and reliance on private vehicles (Farooq, Xie, Stoilova, \& Ahmad, 2019). While the world population is increasing, it is declining in the Baltic States. Nevertheless, the number of cars is growing and cities are facing the same problems. Thus, the right strategy to effectively manage transport services is a major concern for cities around the world. Intelligent mobility system or transport is a critical sub-system of the city. The transport sector consumes a lot of energy and is one of the biggest polluters in cities (Miloševi'c, Miloševi'c, Stevi'c, \& Stanojevi'c, 2019).

The term smart or intelligent mobility appeared at the beginning of the nineties in order to point out at a city with a mobility system more and more dependent on technology and innovation (Papa \& Lauwers, 2015). Some cities that have been more proactive in developing and installing those systems call themselves "smart cities".

Despite various initiatives to promote smart mobility systems in urban areas, little is known about how these systems work in cities, and even less about how to be a flagship city with smart mobility systems (Debnath, Chin, Haque, \& Yuen, 2014). Intelligent and sustainable mobility system limits emissions and waste within the planet's ability to absorb them, uses renewable resources at or below their rates of generation, and uses non-renewable resources at or below the rates of development of renewable substitutes, while minimising the impact on the use of land and generation of noise (Litman, 2008). Smart mobility is related to urban planning, which focuses on collective modes of transportation through extensive use of information and communication technologies (Dudzevičiūtè, Šimelytė, \& Liučvaitienè, 2017). Therefore, it is necessary to formulate a comprehensive concept of the smart mobility system and to select the indicators of smartness that characterise it. It can be argued that the lack of appropriate harmonised concepts and
Evaluation Criteria of Smart City Mobility System Using MCDM Method 
indicators may be the reason for the lack of comprehensive comparative research on smart mobility systems in cities. Most of the current practices for assessing mobility are reflected in the analysis of traffic (movement of vehicles) or mobility (movement of people and goods). They tend to favour road transport over other forms of accessibility, including alternative modes of transport, mobility management and infrastructure.

By adopting a hierarchical model for evaluation of smart mobility, we consider all forms of accessibility, mobility management, technologies, services, systems, infrastructures and measures that improve the quality of life. The aim of this article is to create a hierarchical model for evaluation of smart mobility and to calculate the weights of the selected criteria according to the chosen calculation methodology.

The literature reports on many smart mobility system indicators, evaluation criteria and sub-criteria, it is may help in selecting the most relevant and significant: travel planning and online payment, variable information and message signs, centralised traffic light management systems, bicycle sharing, car sharing, modern parking solutions, and more.

This paper proposes 23 smart mobility system evaluation indicators, which are divided into 5 groups. The hierarchical model of the evaluation system is developed and the significance of the evaluation indicators is determined. This model allows for comparison of the level of "smartness" of the urban mobility systems. This evaluation model is sufficiently versatile, so there are no special requirements for cities that will be compared in terms of smart mobility system. It is recommended that the cities to be compared belong to the same size class: large cities (over 500000 inhabitants) and medium (between 100000 and 500000 inhabitants) (Giffinger, Fertner, Karmar, \& Meijers, 2007), but this is not a prerequisite.

The paper is organised as follows: First, we select the factors and indicators based on the literature review. Then, we present the methodology used for calculation and evaluation. In Section 3, we present the results of the experiment conducted with a group of experts, followed by conclusions.

\section{Literature review}

The concept of the smart city appeared in the second half of the 1980s. According to Google Scholar, the first uses of the term "smart city" can be traced back to the period between 1986 and 1990; it was 
Table 1. Definitions of a smart city

\begin{tabular}{|c|c|}
\hline Definition & Authors \\
\hline $\begin{array}{l}\text { It is the integration of all communication } \\
\text { and information technologies for the effective } \\
\text { management of the urban system }\end{array}$ & $\begin{array}{l}\text { Vukovic, Rzhavtsev, \& } \\
\text { Shmyrev (2019) }\end{array}$ \\
\hline $\begin{array}{l}\text { The smart city is a global trend of urban strategies } \\
\text { aimed at recovering the quality of inhabitants living } \\
\text { in urban areas and at leveraging innovation and high } \\
\text { technologies to solve the difficult problems generated } \\
\text { by high-population density }\end{array}$ & Hajduk (2016) \\
\hline $\begin{array}{l}\text { Smart Cities initiatives try to improve urban } \\
\text { performance by using data, information } \\
\text { and information technologies (IT) to provide more } \\
\text { efficient services to citizens, to monitor and optimize } \\
\text { existing infrastructure, to increase collaboration } \\
\text { among different economic actors, and to encourage } \\
\text { innovative business models in both the private } \\
\text { and public sectors. }\end{array}$ & $\begin{array}{l}\text { Marsal-Llacuna, } \\
\text { Colomer-Llina`s. \& } \\
\text { Mele'ndez-Frigola } \\
\text { (2014) }\end{array}$ \\
\hline $\begin{array}{l}\text { The vision of "Smart Cities" is the urban centre } \\
\text { of the future, made safe, secure environmentally } \\
\text { green, and efficient because all structures - whether } \\
\text { for power, water, transportation, etc. are designed, } \\
\text { constructed, and maintained making use of advanced, } \\
\text { integrated materials, sensors, electronics, } \\
\text { and networks which are interfaced with computerized } \\
\text { systems comprised of databases, tracking, } \\
\text { and decision-making algorithms }\end{array}$ & Hall et al. (2000) \\
\hline
\end{tabular}

used in the literature on urban development innovation and in the context of Japan's Technopolis program.

The concept of a smart city is far from being limited to technology for cities. Several different concepts, definitions and meanings of the notion of "Smart City" are given in Table 1.

Giffinger et al. (2007) identified four components of a smart city: industry, education, governance, and technical infrastructure. This list was expanded within a project of the Regional Science Center at Vienna University of Technology (Albino, Berardi, \& Dangelico, 2015). After examining the models of the smart city, six aspects of the smart city were singled out: smart management, smart economy, smart mobility, smart environment, smart people, and smart living. Each of them has its own specific structure, which forms an integral holistic vision of a smart city.
Evaluation Criteria of Smart City Mobility System Using MCDM Method 
Smart mobility is one aspect of a smart city. Orlowski \& Romanowska (2019) state that smart mobility refers to the area of a smart city representing mobility, or, broadly defined, the components which comprise not only the traditionally understood transportation of people and goods, but also dissemination of information by digital means. The main function of smart mobility is to connect all city's resources people, goods, and information. Battarra Gargiulo, Tremiterra, \& Zucaro (2018) emphasize that smart mobility and its use of ICT could play a potential role in sustainable development of transport systems only if the highest quality and quantity of information is converted into sustainable behaviour by the citizens. So, it can be argued that smart mobility must serve people, not technology.

\subsection{Review of indicators of smart city mobility system}

Scientists do a lot of research about smart city mobility systems, but little work has been done to differentiate the smart mobility system evaluation indicators. In addition, different researchers distinguish different indicators. 30 scientific papers with one or another

Table 2. Sample reviewed articles presenting different factors and indicators

\begin{tabular}{|c|c|c|c|}
\hline Source & Factors & Indicators & Comments \\
\hline $\begin{array}{l}\text { Smart mobility in smart city. } \\
\text { Action taxonomy, ICT intensity } \\
\text { and public benefits (Benevolo, } \\
\text { Dameri, \& D'Auria, 2016) }\end{array}$ & 5 & 52 & $\begin{array}{l}\text { The paper analyses smart mobility } \\
\text { initiatives and investigates the role of ICT } \\
\text { in supporting smart mobility actions }\end{array}$ \\
\hline $\begin{array}{l}\text { Smart mobility in Italian } \\
\text { metropolitan cities: } \\
\text { A comparative analysis } \\
\text { through indicators and actions } \\
\text { (Battarra et al., 2018) }\end{array}$ & 3 & 28 & $\begin{array}{l}\text { The article presents an empirical study } \\
\text { about } 11 \text { Italian metropolitan cities. } \\
\text { It investigates whether and to what } \\
\text { extent the smart city paradigm, applied } \\
\text { to the mobility sector, could enhance } \\
\text { efficiency and liveability of urban areas }\end{array}$ \\
\hline $\begin{array}{l}\text { A methodological framework } \\
\text { for benchmarking smart } \\
\text { transport cities } \\
\text { (Debnath et al., 2014) }\end{array}$ & 3 & 21 & $\begin{array}{l}\text { The paper proposes a comprehensive } \\
\text { and practical framework to benchmark } \\
\text { cities according to the smartness of their } \\
\text { transportation systems }\end{array}$ \\
\hline $\begin{array}{l}\text { A Multicriteria Analysis } \\
\text { Approach for Benchmarking } \\
\text { Smart Transport Cities } \\
\text { (Wibowo \& Grandhi, 2015) }\end{array}$ & 5 & 19 & $\begin{array}{l}\text { The paper develops a multicriteria analysis } \\
\text { approach for evaluating the performance } \\
\text { of different cities based on the smartness } \\
\text { of their transportation systems }\end{array}$ \\
\hline
\end{tabular}


classification of indicators have been analysed in order to select the indicators that comprehensively characterise the smart mobility system and its infrastructure. In these papers, more than 100 different indicators were used to describe the smartness of the urban transport system.

When searching for scientific articles on smart mobility, we found that most articles were published by the Italian research teams. The indicators and factors presented in the articles are different and their number is also different. An example given in Table 2.

Some researchers present calculated weights of smart mobility indicators and factors in their articles (Boselli, Cesarini, Mercorio, \& Mezzanzanica, 2015; Orlowski \& Romanowska, 2019; Wibowo \& Grandhi, 2015), a system of qualitative smart mobility indicators evaluation (Debnath et al., 2014; Garau, Masala, \& Pinna, 2016; Reiber \& Huang, 2018).

\subsection{Review of MCDM method in field of transport}

Many multi-criteria analysis methods such as AHP, TOPSIS, DEMATEL, ELEKTRE, PROMETHEE and many more can be used to evaluate a smart mobility system. The same problem is often solved using identical indicators and their values demonstrate different results. Thus, it is important to consider which of these methods are most appropriate for solving specific tasks. In the scientific articles, researchers (Broniewicz \& Ogrodnik, 2020; Deluka-Tibljaš, Karleuša, \& Dragičević, 2013; Erdogan \& Kaya, 2019; Mardani, Zavadskas, Khalifah, Jusoh, \& MD Nor, 2016) examine the popularity of MCDM methods within the projects associated with transport infrastructure. Based on the literature, it can be stated that the AHP method is one of the most popular, it is used to determine the importance coefficients of smart mobility system indicators (Broniewicz \& Ogrodnik, 2020; Boselli et al., 2015; Castillo \& Pitfield, 2010; DelukaTibljaš et al., 2013, Erdogan \& Kaya, 2019; Farooq et al., 2019; Podvezko, Sivilevicius, \& Podviezko, 2014). The AHP is a powerful tool of multicriteria decision-making developed by Saaty (1980). The AHP is used for solving complex decision-making problems in different areas (e.g. civil engineering, transport, social and economic development, project selection, and materials science) (Podvezko et al., 2014). A number of articles related to the calculation of weights and alternatives for ITS or smart city criteria have been reviewed. Methods used are presented in Table 3.

AHP is one of the most popular MCDM methods for calculating weights and alternative criteria for a smart city, its mobility system, and infrastructure. Therefore, we have chosen the AHP method for further calculations.
Evaluation Criteria of Smart City Mobility System Using MCDM Method 
Table 3. Various MCDM methods used by authors

\begin{tabular}{|c|c|c|}
\hline Author & Method & The title of the article \\
\hline $\begin{array}{l}\text { Biswas, Chatterjee, } \\
\text { \& Choudhuri (2020) }\end{array}$ & CoCoSo & $\begin{array}{l}\text { Selection of commercially available alternative } \\
\text { passenger vehicles in automotive environment }\end{array}$ \\
\hline $\begin{array}{l}\text { Broniewicz \& } \\
\text { Ogrodnik (2020) }\end{array}$ & $\begin{array}{l}\text { AHP } \\
\text { Fuzzy AHP } \\
\text { TOPSIS } \\
\text { PROMETHEE }\end{array}$ & $\begin{array}{l}\text { Multi-criteria analysis of transport infrastructure } \\
\text { projects }\end{array}$ \\
\hline $\begin{array}{l}\text { Krmac \& Djordjević } \\
\text { (2019) }\end{array}$ & TOPSIS & $\begin{array}{l}\text { Evaluation of the TCIS Influence on the capacity } \\
\text { utilization using the TOPSIS method: Case studies } \\
\text { of Serbian and Austrian railways }\end{array}$ \\
\hline $\begin{array}{l}\text { Erdogan \& Kaya } \\
\text { (2019) }\end{array}$ & $\begin{array}{l}\text { Fuzzy AHP } \\
\text { Stochastic TOPSIS }\end{array}$ & $\begin{array}{l}\text { Prioritizing failures by using hybrid multi criteria } \\
\text { decision making methodology with a real case } \\
\text { application }\end{array}$ \\
\hline $\begin{array}{l}\text { Stanković, Gladović, } \\
\text { \& Popović (2019) }\end{array}$ & $\begin{array}{l}\text { Fuzzy AHP } \\
\text { Rough AHP }\end{array}$ & $\begin{array}{l}\text { Determining the importance of the criteria } \\
\text { of traffic accessibility using fuzzy AHP and rough } \\
\text { AHP method }\end{array}$ \\
\hline Farooq et al., 2019 & AHP & $\begin{array}{l}\text { Multicriteria Evaluation of Transport Plan for High- } \\
\text { Speed Rail: An Application to Beijing-Xiongan }\end{array}$ \\
\hline $\begin{array}{l}\text { Zhu, Lia, \& Fengc } \\
(2019)\end{array}$ & $\begin{array}{l}\text { AHP } \\
\text { TOPSIS }\end{array}$ & Is smart city resilient? Evidence from China \\
\hline $\begin{array}{l}\text { Miloševi'c et al. } \\
(2019)\end{array}$ & AHP & $\begin{array}{l}\text { Smart City: Modelling Key Indicators in Serbia } \\
\text { Using IT2FS }\end{array}$ \\
\hline $\begin{array}{l}\text { Kicinski \& Solecka } \\
\text { (2018) }\end{array}$ & $\begin{array}{l}\text { AHP } \\
\text { Electre III }\end{array}$ & $\begin{array}{l}\text { Application of MCDA/MCDM methods } \\
\text { for an integrated urban public transportation } \\
\text { system - case study, city of Cracow }\end{array}$ \\
\hline $\begin{array}{l}\text { Bhandari \& } \\
\text { Nalmpantis (2018) }\end{array}$ & $\begin{array}{l}\text { AHP } \\
\text { PROMETHEE } \\
\text { TOPSIS } \\
\text { MOORA }\end{array}$ & $\begin{array}{l}\text { Application of Various Multiple Criteria Analysis } \\
\text { Methods for the Evaluation of Rural Road Projects }\end{array}$ \\
\hline Boselli et al. (2015) & AHP & $\begin{array}{l}\text { Applying the AHP to Smart Mobility Services: } \\
\text { A Case Study }\end{array}$ \\
\hline $\begin{array}{l}\text { Wibowo \& Grandhi } \\
\text { (2015) }\end{array}$ & Fuzzy AHP & $\begin{array}{l}\text { A Multicriteria Analysis Approach for Benchmarking } \\
\text { Smart Transport Cities }\end{array}$ \\
\hline $\begin{array}{l}\text { Podvezko, } \\
\text { Sivilevicius, } \\
\text { \& Podviezko (2014) }\end{array}$ & AHP & $\begin{array}{l}\text { Scientific applications of the AHP method } \\
\text { in transport problems }\end{array}$ \\
\hline $\begin{array}{l}\text { Deluka-Tibljaš et al. } \\
\text { (2013) }\end{array}$ & $\mathrm{MCA}$ & $\begin{array}{l}\text { Review of multicriteria-analysis methods } \\
\text { application in decision making about transport } \\
\text { infrastructure }\end{array}$ \\
\hline
\end{tabular}


Table 3. Continuation

\begin{tabular}{|c|c|c|}
\hline Author & Method & The title of the article \\
\hline $\begin{array}{l}\text { Turcksin, Bernardini, } \\
\text { \& Macharis (2011) }\end{array}$ & $\begin{array}{l}\text { AHP } \\
\text { PROMETHEE }\end{array}$ & $\begin{array}{l}\text { A combined AHP-PROMETHEE approach } \\
\text { for selecting the most appropriate policy scenario } \\
\text { to stimulate a clean vehicle fleet }\end{array}$ \\
\hline $\begin{array}{l}\text { Castillo \& Pitfield } \\
\text { (2010) }\end{array}$ & $\mathrm{AHP}$ & $\begin{array}{l}\text { ELASTIC - A methodological framework } \\
\text { for identifying and selecting sustainable transport } \\
\text { indicators }\end{array}$ \\
\hline $\begin{array}{l}\text { Moreira, Dupont, } \\
\& \text { Vellasco (2009) }\end{array}$ & $\begin{array}{l}\text { PROMETHEE } \\
\text { Fuzzy PROMETHEE }\end{array}$ & $\begin{array}{l}\text { PROMETHEE and Fuzzy PROMETHEE Multicriteria } \\
\text { Methods for Ranking Equipment Failure Modes }\end{array}$ \\
\hline
\end{tabular}

\section{Methodology}

Weights for multicriteria evaluation criteria are based on expert judgement, i.e., expert evaluations provide the basis for determining subjective criteria weights. The opinions of individual experts are often contradictory. That is to say, the importance and priority ranking of individual expert criteria evaluation will vary.

It is important to use expert methods to determine the significance of indicators, otherwise, it is difficult to assess the reliability and alternatives of the study. Evaluations depend on the qualifications of the experts, specifics of the job, interest in obtaining certain evaluation results, work experience, etc. Criteria weights as aggregated averages of expert opinions can be used in a multicriteria evaluation provided that there is no contradiction between expert assessments, more precisely, opinions are proven to be statistically consistent (Podvezko, \& Podviezko, 2014).

\subsection{Gauging the level of concordance of expert opinions}

The compatibility of evaluations can be determined using Kendall concordance coefficient, which is calculated by Eq. (1) (Sivilevičius, 2011):

$$
W=\frac{12 S}{p^{2}\left(m^{3}-m\right)},
$$

where $S$ - sum of the squares of the total deviation from the evaluation results; $p$ - the number of experts; $m$ - the number of criteria.

The sum of squares of the deviation from the overall mean is calculated using Eq. (2):

$$
S=\sum_{j=1}^{m}\left(R_{j}-\bar{R}\right)^{2}
$$

where $R_{j}$ - the sum of the criteria rank; $\bar{R}$ - the overall average. 
The concordance coefficient $W$ is a calculated variable that may take a random value. Therefore, significance of the coefficient must be calculated. The significance of the concordance coefficient is determined by Eq. (3):

$$
\chi^{2}=p(m-1) W .
$$

The consistency of the expert evaluation is determined by calculating the minimum value of the concordance coefficient using Eq. (4):

$$
W_{\text {crit }}=\frac{\chi_{\nu \propto}^{2}}{p(m-1)} .
$$

If we get that $W>W_{\text {crit, }}$ it confirms that the expert opinions are harmonised.

\subsection{Determination of subjective significance of indicators using APH method}

AHP (Analytic Hierarchy Process) method, proposed by Saaty (1980), is one of the most well-known and most frequently applied in the world. This method is used in the majority of cases evaluating various transport projects involving organisational, technological, environmental and infrastructure solutions. AHP is particularly useful in terms of its ability to decompose a complex problem into its components and ease of use (Turcksin et al., 2011). The AHP method allows comparisons of individual indicators (criteria) in pairs, giving them importance in relation to each other. It elicits subjective comparisons from the decision-maker, and then synthesises these judgements into ratio-scale weights (Castillo \& Pitfield, 2010).

The AHP method is convenient because it is easier for the experts to compare two criteria at a time, rather than all at once. It allows using qualitative assessment criteria to provide a quantitative assessment. The method is based on a pairwise comparison matrix P. Experts compare all evaluated criteria $R_{i}$ and $R_{j}(i, j=1, \ldots, m), m$ - number of criteria. Saaty (2008) suggested using a five point (1-3-5-7-9) or sometimes nine-point scale (1-2-3-4-5-6-7-8-9), often used in practice (Table 4).

Elements of matrix $P$ are numbers from $p_{i j}=1$, where the meanings of the two compared criteria are equal to $p_{i j}=9$, when criterion $R_{i}$ is incomparably more important than criterion $R_{j}$. The elements $p_{i j}$ of matrix $P$ can be regarded as ratios of weights $R_{i}$ ir $R_{j}$ :

$$
p_{i j}=\frac{w_{i}}{w_{j}}
$$


Table 4. The fundamental scale

of absolute numbers (source: Saaty, 2008)

\begin{tabular}{|c|c|c|c|}
\hline $\begin{array}{l}\text { Degree } \\
\text { of importance }\end{array}$ & \multicolumn{2}{|l|}{ Definition } & Explanation \\
\hline 1 & \multicolumn{2}{|l|}{ Equal importance } & $\begin{array}{l}\text { Two activities contribute equally } \\
\text { to the objective }\end{array}$ \\
\hline 2 & \multicolumn{3}{|l|}{ Weak or slight } \\
\hline 3 & \multicolumn{2}{|l|}{ Moderate importance } & $\begin{array}{l}\text { Experience and judgement slightly } \\
\text { favour one activity over another }\end{array}$ \\
\hline 4 & \multicolumn{3}{|l|}{ Moderate plus } \\
\hline 5 & \multicolumn{2}{|l|}{ Strong importance } & $\begin{array}{l}\text { Experience and judgement strongly } \\
\text { favour one activity over another }\end{array}$ \\
\hline 6 & \multicolumn{3}{|l|}{ Strong plus } \\
\hline 7 & \multicolumn{2}{|c|}{$\begin{array}{l}\text { Very strong or demonstrated } \\
\text { importance }\end{array}$} & $\begin{array}{l}\text { An activity is favoured very strongly over } \\
\text { another, its dominance demonstrated } \\
\text { in practice }\end{array}$ \\
\hline 8 & \multicolumn{3}{|l|}{ Very very strong } \\
\hline 9 & \multicolumn{2}{|l|}{ Extreme importance } & $\begin{array}{l}\text { The evidence favouring one activity over } \\
\text { another is of the highest possible order } \\
\text { of affirmation }\end{array}$ \\
\hline $\begin{array}{l}\text { Reciprocal } \\
\text { of above }\end{array}$ & \multicolumn{2}{|c|}{$\begin{array}{l}\text { If activity } i \text { has one of the above non-zero } \\
\text { numbers assigned to it when compared } \\
\text { with activity } j \text {, then } j \text { has the reciprocal } \\
\text { value when compared with } i\end{array}$} & A reasonable assumption \\
\hline $1.1-1.9$ & \multicolumn{2}{|l|}{ If the activities are very close } & $\begin{array}{l}\text { Maybe difficult to assign the best } \\
\text { value but when compared with other } \\
\text { contrasting activities the size } \\
\text { of the small numbers would not be too } \\
\text { noticeable, yet they can still indicate } \\
\text { the relative importance of the activities. }\end{array}$ \\
\hline & $=\left(\begin{array}{cccc}p_{21} & p_{22} & \cdots & p_{m m} \\
\vdots & \vdots & \ddots & \vdots \\
p_{m 1} & p_{m 2} & \cdots & p_{m m}\end{array}\right)=$ & $\begin{array}{ccc}\frac{w_{1}}{w_{1}} & \frac{w_{2}}{w_{1}} & . \\
\frac{w_{2}}{w_{1}} & \frac{w_{2}}{w_{2}} & . \\
\vdots & \vdots \\
\frac{w_{m}}{w_{1}} & \frac{w_{m}}{w_{2}} & .\end{array}$. & $\left.\begin{array}{cc}\cdots & \frac{w_{1}}{w_{m}} \\
\cdots & \frac{w_{2}}{w_{m}} \\
\ddots & \vdots \\
\cdots & \frac{w_{m}}{w_{m}}\end{array}\right)$. \\
\hline
\end{tabular}

The matrix is reciprocal $p_{i j}=p_{j i}^{-1}$. In order to determine the weights, the problem of the real values of matrix $P$ and the real vectors $w=\left(w_{1}, w_{2}, \ldots, w_{m}\right)^{\mathrm{T}}$ is solved. 
The degree of compatibility of individual assessments of each expert is determined by consistency index C.I. and consistency ratio C.R. The Compatibility Index is defined (Saaty, 1980) as the ratio expressed by the formula:

$$
\text { C.I. }=\frac{\left(\lambda_{\max }-m\right)}{(m-1)} .
$$

The better the matrix compatibility, the lower the compatibility index value is. Ideally C.I. $=0$.

The ratio of specific matrix computed compatibility index C.I. and the average random index R.I. is called the compatibility ratio; it evaluates the degree of compatibility of the matrix:

$$
\text { C.R. }=\frac{\text { C.I. }}{\text { R.I. }} \leq 0.1 .
$$

The matrix is considered compatible when compatibility ratio C.R. is less than 0.1 (Saaty, 1980).

\subsection{Determination of subjective significance of indicators using ranking method}

Using the expert ranking method, it is necessary to reform the ranking. The purpose of rearrangement is to assign weights in descending order of the rank. Doing so would give the top rank the highest value. The most accurate result is the linear transformation of estimates. In this case, the values of criteria weights can be calculated using the formula (Sivilevičius, 2011):

$$
w_{i}=\frac{(m+1)-\overline{R_{j}}}{\sum_{j=1}^{m} \overline{R_{j}}},
$$

where $\overline{R_{j}}$ - the average (normative) of the criteria rank.

\section{Evaluation criteria of the smart mobility system}

In order to create the hierarchical evaluation system model, 5 factors and 23 indicators were selected on the basis of literature review. In the context of this paper, these factors are groups of indicators describing different measures that could make a mobility system smart. All 5 groups are closely related to each other, as is the whole mobility system. 


\subsection{Selection of indicators for the smart city mobility system}

Evaluation Criteria of Smart City Mobility System Using MCDM Method

5 factors and 23 indicators have been selected using the exclusion method (Figure 1).

The following factors were distinguished:

A. Motor Travel and Congestion Reduction Measures;

B. Pollution Abatement Measures;

C. Travel Safety and Accident Reduction Measures;

D. Traffic Management Tools and Services;

E. Smart Infrastructure Measures.

The following indicators have been distinguished:

A1. Car sharing. Vehicle rental services that substitute for private automobile ownership;

A2. Bike sharing. Bike rental services that substitute for private automobile ownership;

A3. Low-power electric vehicle sharing. Low-power electric vehicle rental services that substitute for private automobile ownership;

A4. Carpooling. Also called ridesharing, the purpose of the system is to bring together the users, who travel in the same direction with the same vehicle;

A5. Park \& Ride system. Park and ride facilities are parking lots with public transport connections that allow commuters and other people heading to city centres to leave their vehicles and transfer to a bus, rail system, or carpool for the remainder of the journey;

B1. Use of alternative fuels and renewable energy sources in the public transport. The alternative to fossil fuels: electricity, liquefied gas, methane, hydrogen, biodiesel, fuel cells;

B2. Environmentally friendly private vehicles. These include electric, hydrogen vehicles and others that use alternative fuels rather than fossil fuels.

B3. Modern parking solutions. These are the parking lots with a routing system and/or reservation of parking space;

B4. Emissions Testing and Mitigation. The system uses advanced sensors to monitor areas of polluted air and control access to such areas;

C1. Smart pedestrian and bicycle crossings. Built-in hardware detects pedestrians and activates roadside light panels and vertical panels on either side of the road, sensor-driven cycling signal management, creating green waves.

C2. Smart speed reduction. Sensors of the automatic speed reduction system detect when the number of cars exceeds the set limits on the streets and automatically reduce the speed limit; 
C3. Traffic monitoring systems. The travel safety system helps create a safe environment for passengers, drivers and support staff. The sensors monitor the environment in the vehicles, stations, parking lots, basic transit infrastructure;

C4. Automated control of safe travel for commercial vehicles. This is a system that gives drivers alerts on their driving characteristics, vehicle condition and road condition. The system monitors the performance of components such as tyres and brakes and warns of impending failure. A start-up compatible alcoblock can be installed;

C5. Autonomous vehicles. The equipment installed in the cars tracks the environment, has databases of the road and surrounding areas that are constantly scanned. The system provides information to the driver and helps drive safely. Autonomous driving is also possible in some sections;

D1. Traffic lights management system. Controlled and coordinated or adaptive control traffic lights, automatically controlled in response to traffic conditions or upon request of pedestrians;

D2. Vehicular communication systems. Vehicle-to-everything (V2X) system components monitor the environment. The system incorporates vehicle-to-vehicle (V2V) and vehicleto-infrastructure (V2I) technologies, which detect and prevent potential obstacles and alert other road users. 5G internet connectivity provides autonomous car development opportunities;

D3. Information, travel planning and online payment. Electronic ticketing on-board, interactive information on routes, timetables and waiting times, travel planner for optimal routes, dedicated website for travel tickets;

D4. Variable information and message signs. Automatic road signs (variable message), SMS traffic alerts, electronic payment of parking, dedicated info applications for mobile devices, real-time public transport information;

E1. Special traffic lanes. Only vehicles meeting the lane marking requirements (buses, high-occupancy, electric cars, taxis) can drive in these lanes. Smart special lanes must be equipped with sensors to detect offenders - the ANPR system is used;

E2. Restricted traffic zones. Smart restricted traffic zones capture vehicles entering the area. If the system does not find a specific vehicle on the list of vehicles allowed to enter the area, a fine will be imposed; 


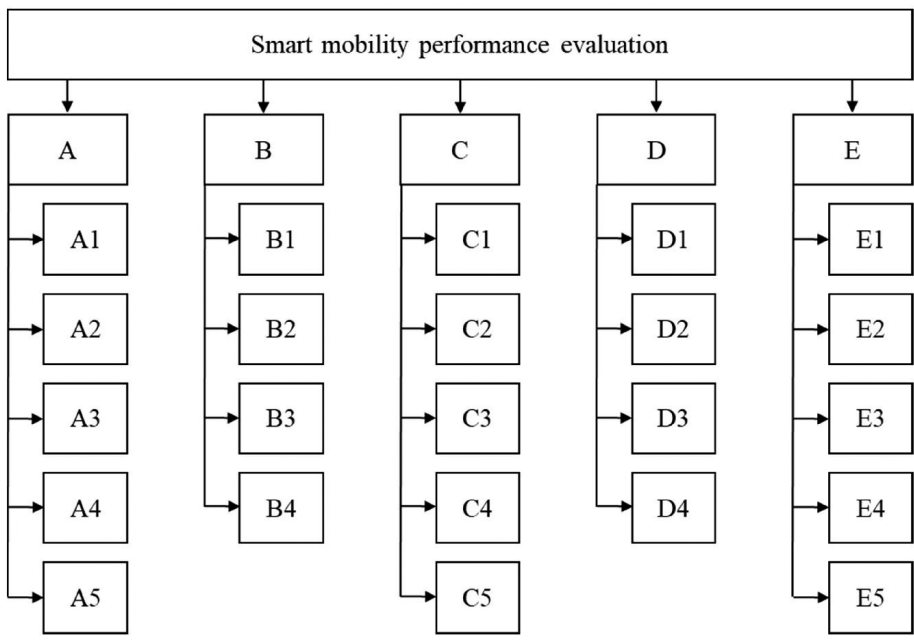

Figure 1. Hierarchical model for evaluation of smart mobility

E3. Electric vehicles charging stations, hydrogen stations. These include electric vehicles charging and hydrogen filling stations, and other smart electric vehicles charging applications;

E4. Smart street surfacing. These are the surfaces of the street specially equipped: illuminated, heated, de-icing, charging electric vehicles, etc.;

E5. Smart street lighting. Smart street lighting controls work with climatic conditions, time of the day, traffic volume, and more. The main advantage of this system is the centralised control of all luminaries connected to the system, remote lighting-level change, information on luminary malfunctions, pavement, traffic conditions.

The selected indicators are grouped into five groups (factors) according to their influence on the mobility system. The model for evaluation of the smart city mobility system and its infrastructure was created (Figure 1).

The factors and indicators shown in Figure 1 are used as criteria and sub-criteria in the calculation of their weights by AHP and ranking methods. After calculating the weights of the factors and indicators using both methods, the final weights of the indicators that can be used for comparison of the smartness levels of city mobility systems are calculated.
Evaluation Criteria of Smart City Mobility System Using MCDM Method 


\subsection{Calculation of subjective significance of the indicators}

Based on the structure of the presented hierarchy model, five survey questionnaires were prepared for the assessment of individual factor indicators and the sixth questionnaire - for factor assessment. Questionnaires were forwarded to the experts for completion in two ways: ranking the factors/indicators and completing the paired comparison tables drawn up by the AHP method. The experts were selected strictly according to their competence in the fields of transportation and civil engineering. These are the heads of the following institutions: ME "Susisiekimo paslaugos" for transport services in Vilnius City (3), Lithuanian Road Administration under the Ministry of Transport and Communications (1), the Ministry of Transport and Communications of the Republic of Lithuania (1), VGTU Road Research Institute staff with a scientific degree (3), researchers of the Department of Roads, Faculty of Environmental Engineering, VGTU (5) and researchers of the VGTU Faculty of Transport Engineering (2). The total of 15 experts were interviewed one by one or in exceptional cases in small groups, as the AHP method is quite complicated and requires an explanation by an interviewer.

Factor and indicator weights, compatibility of expert opinions and other necessary calculations were performed with the Microsoft Office Excel package using the above-presented formulas.

$W_{\text {crit }}$ was calculated first with significance levels $\alpha=0.5$ and $v=5-1=4$ or $v=4-1=3$, depending on the number of factors and the number of indicators in the group.

The Kendall concordance coefficients for $W$ factors and indicators were calculated after receiving 10 completed questionnaires. The Kendall concordance coefficients, calculated for the factors (A, B, C, D, E) and the factor "Motor travel and congestion reduction measures" (A1, A2, A3, A4, A5), $W<W_{\text {crit }}=0.15813$, which means that expert assessments are

Table 5. Comparison of calculated Kendal concordance coefficient with its minimum value

\begin{tabular}{lcc}
\hline \multicolumn{1}{c}{ Factors/indicators } & $\begin{array}{c}\text { Kendall concordance } \\
\text { coefficient } \boldsymbol{W}\end{array}$ & $\boldsymbol{W}_{\text {crit }}$ \\
\hline $\mathrm{A}, \mathrm{B}, \mathrm{C}, \mathrm{D}, \mathrm{E}, \mathrm{F}$ & 0.17244 & 0.15813 \\
$\mathrm{~A} 1, \mathrm{~A} 2, \mathrm{~A} 3, \mathrm{~A} 4, \mathrm{~A} 5$ & 0.16000 & 0.15813 \\
$\mathrm{~B} 1, \mathrm{~B} 2, \mathrm{~B} 3, \mathrm{~B} 4$ & 0.65156 & 0.17366 \\
$\mathrm{C1}, \mathrm{C} 2, \mathrm{C3}, \mathrm{C4}, \mathrm{C5}$ & 0.19378 & 0.15813 \\
$\mathrm{D} 1, \mathrm{D} 2, \mathrm{D} 3, \mathrm{D4}$ & 0.41511 & 0.17366 \\
$\mathrm{E} 1, \mathrm{E2}, \mathrm{E3}, \mathrm{E4}, \mathrm{E5}$ & 0.19378 & 0.15813 \\
\hline
\end{tabular}


Table 6. An expert-completed pairwise comparison matrix and calculation results

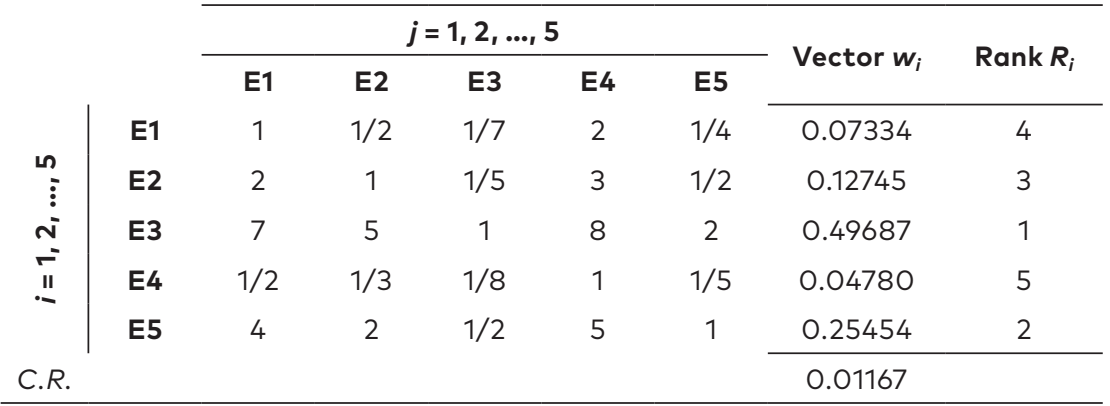

contradictory. After interviewing 5 additional experts and calculating Kendall's concordance coefficients for $W$ factors and their indicators, it was found that all factors and indicators $W>W_{\text {crit }}$ (Table 5), therefore, it can be stated that the expert estimates are not contradictory and opinion averages can be used in multicriteria evaluation.

Expert opinions were the most consistent when evaluating the indicators of pollution abatement measures $(W=0.65156)$ and traffic management tools and services $(W=0.41511)$. Most inconsistent expert opinions were on motor travel and congestion reduction measures $(W=0.16000)$. This indicates that some of the indicators for this factor collected a similar number of expert-ranked estimates.

The AHP matrices were immediately checked for compatibility, and when the matrix was found to be misaligned, the errors were explained to the expert and the matrix data were corrected. Otherwise, many matrices would have to be declared ineligible for calculations. Alternatively, if an error was found, an expert was asked to refill the matrices.

After obtaining criteria rank tables and pairs of comparison matrices filled in by the expert, calculations were performed: true vectors $w_{i}$ of each of the six matrices of each expert were calculated, the rankings were determined, the maximum true values of $\lambda_{\max }$ were calculated, compatibility indices C.I. and compatibility relations C.R. were determined. All six matrices completed by fifteen experts (90 in total) were harmonised, C.R. $<0.1$. Therefore, it can be stated that these experts were consistent in completing the pairing comparison matrices and did not provide contradictory estimates. The following is an example of a completed pairwise comparison matrix with calculations performed by a random expert filled in by a random pairwise comparison matrix and the results of its calculations (Table 6).
Evaluation Criteria of Smart City Mobility System Using MCDM Method 
After calculating all 90 matrices and ranking them according to their vector $w_{i}$ it was found that the ranks calculated in all matrices correspond to the ranks given by the experts in the survey questionnaires. The criteria weights $w_{i}$, summarised and calculated from the evaluations provided by all the experts, are calculated as arithmetic averages of the AHP weights.

\section{Results}

The averages and weightings of all experts' weighting factors calculated by the AHP method were calculated according to formula (9) are presented in Table 7.

Table 7. Summarised criteria weights based on questionnaires completed by all experts

\begin{tabular}{|c|c|c|c|c|c|c|}
\hline \multirow[t]{2}{*}{ Method } & \multirow[b]{2}{*}{\begin{tabular}{|l}
\multicolumn{1}{|r}{ Factors } \\
Motor \\
travel and \\
congestion \\
reduction \\
measures \\
(A)
\end{tabular}} & \multicolumn{5}{|c|}{ Indicators } \\
\hline & & $\begin{array}{l}\text { Car sharing } \\
\text { (A1) }\end{array}$ & $\begin{array}{l}\text { Bike sharing } \\
\text { (A2) }\end{array}$ & $\begin{array}{l}\text { Low-power } \\
\text { electric } \\
\text { vehicle } \\
\text { sharing } \\
\text { (A3) }\end{array}$ & $\begin{array}{l}\text { Carpooling } \\
\text { (A4) }\end{array}$ & $\begin{array}{l}\text { Park and Ride } \\
\text { system } \\
\text { (A5) }\end{array}$ \\
\hline $\begin{array}{l}\text { AHP } \\
\text { method }\end{array}$ & 0.26112 & 0.17346 & 0.21920 & 0.18651 & 0.09624 & 0.32459 \\
\hline $\begin{array}{l}\text { Ranking } \\
\text { method }\end{array}$ & 0.24889 & 0.19111 & 0.21778 & 0.20000 & 0.13778 & 0.25333 \\
\hline \multirow[t]{2}{*}{ Average } & 0.25501 & 0.18229 & 0.21849 & 0.19326 & 0.11701 & 0.28896 \\
\hline & $\begin{array}{l}\text { Pollution } \\
\text { abatement } \\
\text { measures } \\
\text { (B) }\end{array}$ & $\begin{array}{l}\text { Use of } \\
\text { alternative } \\
\text { fuels and } \\
\text { renewable } \\
\text { energy } \\
\text { sources } \\
\text { in public } \\
\text { transport } \\
\text { (B1) }\end{array}$ & $\begin{array}{l}\text { Environmentally } \\
\text { friendly vehicles } \\
\text { (B2) }\end{array}$ & $\begin{array}{l}\text { Modern } \\
\text { parking } \\
\text { solutions } \\
\text { (B3) }\end{array}$ & $\begin{array}{l}\text { Emissions } \\
\text { Testing and } \\
\text { Mitigation } \\
\text { (B4) }\end{array}$ & \\
\hline $\begin{array}{l}\text { AHP } \\
\text { method }\end{array}$ & 0.14994 & 0.38453 & 0.43408 & 0.08877 & 0.09262 & \\
\hline $\begin{array}{l}\text { Ranking } \\
\text { method }\end{array}$ & 0.16000 & 0.33333 & 0.34667 & 0.15333 & 0.16667 & \\
\hline Average & 0.15497 & 0.35893 & 0.39038 & 0.12105 & 0.12965 & \\
\hline
\end{tabular}


Table 7. Continuation

\begin{tabular}{|c|c|c|c|c|c|c|}
\hline \multirow[t]{2}{*}{ Method } & \multirow[b]{2}{*}{\begin{tabular}{l}
\multicolumn{1}{c}{ Factors } \\
Travel safety \\
and accident \\
reduction \\
measures \\
(C)
\end{tabular}} & \multicolumn{5}{|c|}{ Indicators } \\
\hline & & $\begin{array}{l}\text { Smart } \\
\text { pedestrian } \\
\text { and bicycle } \\
\text { crossings } \\
\text { (C1) }\end{array}$ & $\begin{array}{l}\text { Smart speed } \\
\text { reduction } \\
\text { (C2) }\end{array}$ & $\begin{array}{l}\text { Traffic } \\
\text { monitoring } \\
\text { systems } \\
\text { (C3) }\end{array}$ & $\begin{array}{l}\text { Automated } \\
\text { control } \\
\text { of safe } \\
\text { travel for } \\
\text { commercial } \\
\text { vehicles } \\
\text { (C4) }\end{array}$ & $\begin{array}{l}\text { Autonomous } \\
\text { vehicles } \\
\text { (C5) }\end{array}$ \\
\hline $\begin{array}{l}\text { AHP } \\
\text { method }\end{array}$ & 0.20281 & 0.25708 & 0.26488 & 0.17968 & 0.07913 & 0.21923 \\
\hline $\begin{array}{l}\text { Ranking } \\
\text { method }\end{array}$ & 0.20444 & 0.24000 & 0.23556 & 0.20444 & 0.12444 & 0.19556 \\
\hline \multirow[t]{2}{*}{ Average } & 0.20363 & 0.24854 & 0.25022 & 0.19206 & 0.10179 & 0.20740 \\
\hline & \begin{tabular}{|l} 
Traffic \\
management \\
tools and \\
services \\
(D)
\end{tabular} & $\begin{array}{l}\text { Traffic light } \\
\text { management } \\
\text { system } \\
\text { (D1) }\end{array}$ & $\begin{array}{l}\text { Vehicular } \\
\text { communication } \\
\text { systems } \\
\text { (D2) }\end{array}$ & $\begin{array}{l}\text { Information, } \\
\text { travel } \\
\text { planning } \\
\text { and online } \\
\text { payment } \\
\text { (D3) }\end{array}$ & $\begin{array}{l}\text { Variable } \\
\text { information } \\
\text { and } \\
\text { message } \\
\text { signs } \\
\text { (D4) }\end{array}$ & \\
\hline $\begin{array}{l}\text { AHP } \\
\text { method }\end{array}$ & 0.24799 & 0.39078 & 0.35590 & 0.14653 & 0.10679 & \\
\hline $\begin{array}{l}\text { Ranking } \\
\text { method }\end{array}$ & 0.23556 & 0.33333 & 0.30667 & 0.20000 & 0.16000 & \\
\hline \multirow[t]{2}{*}{ Average } & 0.24178 & 0.36206 & 0.33129 & 0.17327 & 0.13340 & \\
\hline & \begin{tabular}{|l|} 
Smart \\
infrastructure \\
measures \\
$(E)$
\end{tabular} & $\begin{array}{l}\text { Special } \\
\text { traffic lanes } \\
\text { (for public } \\
\text { or special } \\
\text { transport) } \\
\text { (E1) }\end{array}$ & $\begin{array}{l}\text { Restricted } \\
\text { traffic zones } \\
(E 2)\end{array}$ & $\begin{array}{l}\text { Electric } \\
\text { vehicles } \\
\text { charging } \\
\text { stations, } \\
\text { hydrogen } \\
\text { stations } \\
\text { (E3) }\end{array}$ & $\begin{array}{l}\text { Smart } \\
\text { street } \\
\text { surfacing } \\
\text { (E4) }\end{array}$ & $\begin{array}{l}\text { Smart street } \\
\text { lighting } \\
\text { (E5) }\end{array}$ \\
\hline $\begin{array}{l}\text { AHP } \\
\text { method }\end{array}$ & 0.13813 & 0.33229 & 0.21086 & 0.17497 & 0.16211 & 0.11977 \\
\hline $\begin{array}{l}\text { Ranking } \\
\text { method }\end{array}$ & 0.15111 & 0.24000 & 0.23556 & 0.20444 & 0.12444 & 0.19556 \\
\hline Average & 0.14462 & 0.28615 & 0.22321 & 0.18971 & 0.14328 & 0.15767 \\
\hline
\end{tabular}

The calculated weighting sequence (ranks) may not always be the same using AHP and ranking methods. The rankings for some factors such as Travel Safety and Accident Reduction measures and Smart Infrastructure measures did not match. 


\subsection{Analysis of Result Comparison}

Rank weights calculated by AHP and ranking method are different, so the results are shown in the diagram (Figure 2).

Criteria weighting done by both methods indicates that the AHP method is "more sensitive" than the expert ranking method. The

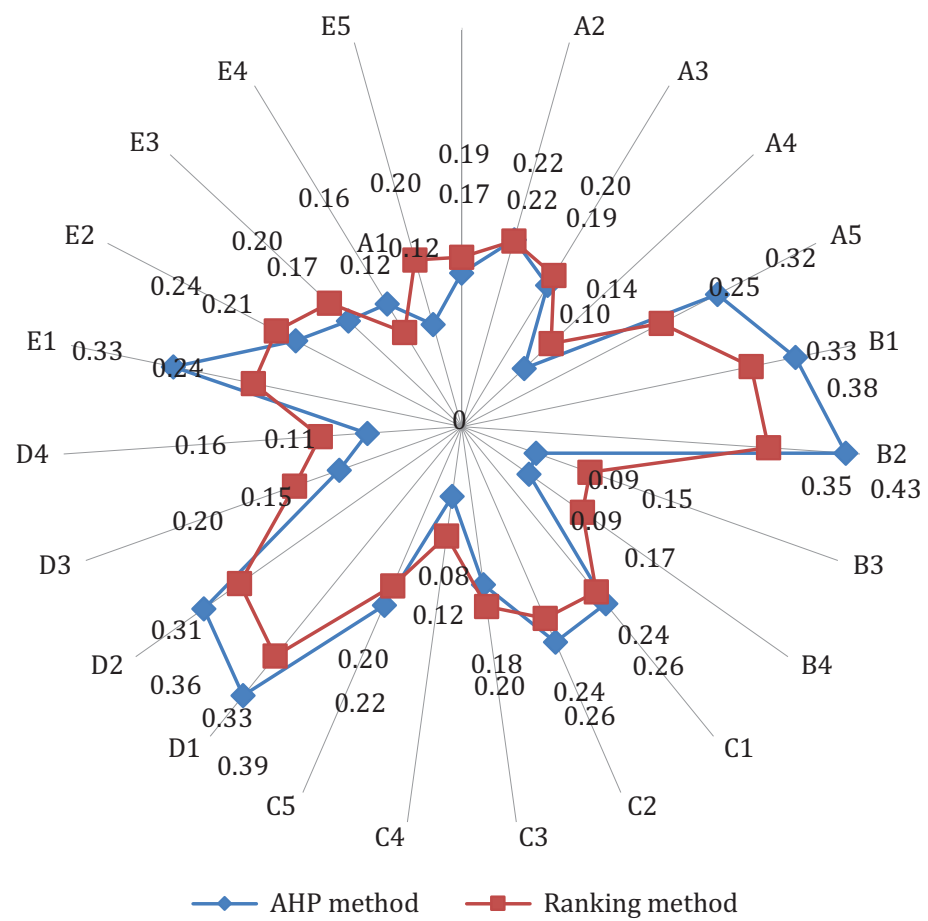

Legend:

A1: Car sharing

A2: Bike sharing

A3: Low-power electric vehicle sharing

A4: Carpooling

A5: Park and Ride system

B1: Use of alternative fuels and renewable energy sources in public transport

B2: Environmentally friendly vehicles

B3: Modern parking solutions

B4: Emissions Testing and Mitigation

C1: Smart pedestrian and bicycle crossings

C2: Smart speed reduction

C3: Traffic monitoring systems

C4: Automated control of safe travel for commercial vehicles

C5: Autonomous vehicles

D1: Traffic light management system D2: Vehicular communication systems D3: Information, travel planning and online payment

D4: Variable information and message signs

E1: Special traffic lanes

E2: Restricted traffic zones

E3: Electric vehicles charging stations, hydrogen stations

E4: Smart street surfacing

E5: Smart street lighting

Figure 2. Comparison of criteria weights calculated by different methods 
AHP-weighted maximum difference between indicators of Pollutant Evaluation Criteria of Smart City Mobility System Abatement Measures, Environmentally Friendly Vehicles and Modern Parking Solutions measures is by 15 percentage points higher than that Using MCDM calculated by the ranking method.

\subsection{Summarised indicator weight}

We will use averages obtained by both methods for further research. Final indicator priorities are calculated according to Saaty (2008) methodology. "We need to multiply each ranking by the priority of its criterion or subcriterion and add the resulting weighs for each alternative to get its final priority. We call this part of the process, synthesis" (Saaty, 2008). Rank weights by factors and indicators are shown in Figure 3.

According to the Lithuanian experts, the most important indicators of smart mobility systems are Traffic Light Management System (0.08754), Vehicular Communication Systems (0.08010) and Park and Ride System (0.07369). Motor Travel and Congestion Reduction Measures and Traffic Management Tools and Services factors have the greatest significance

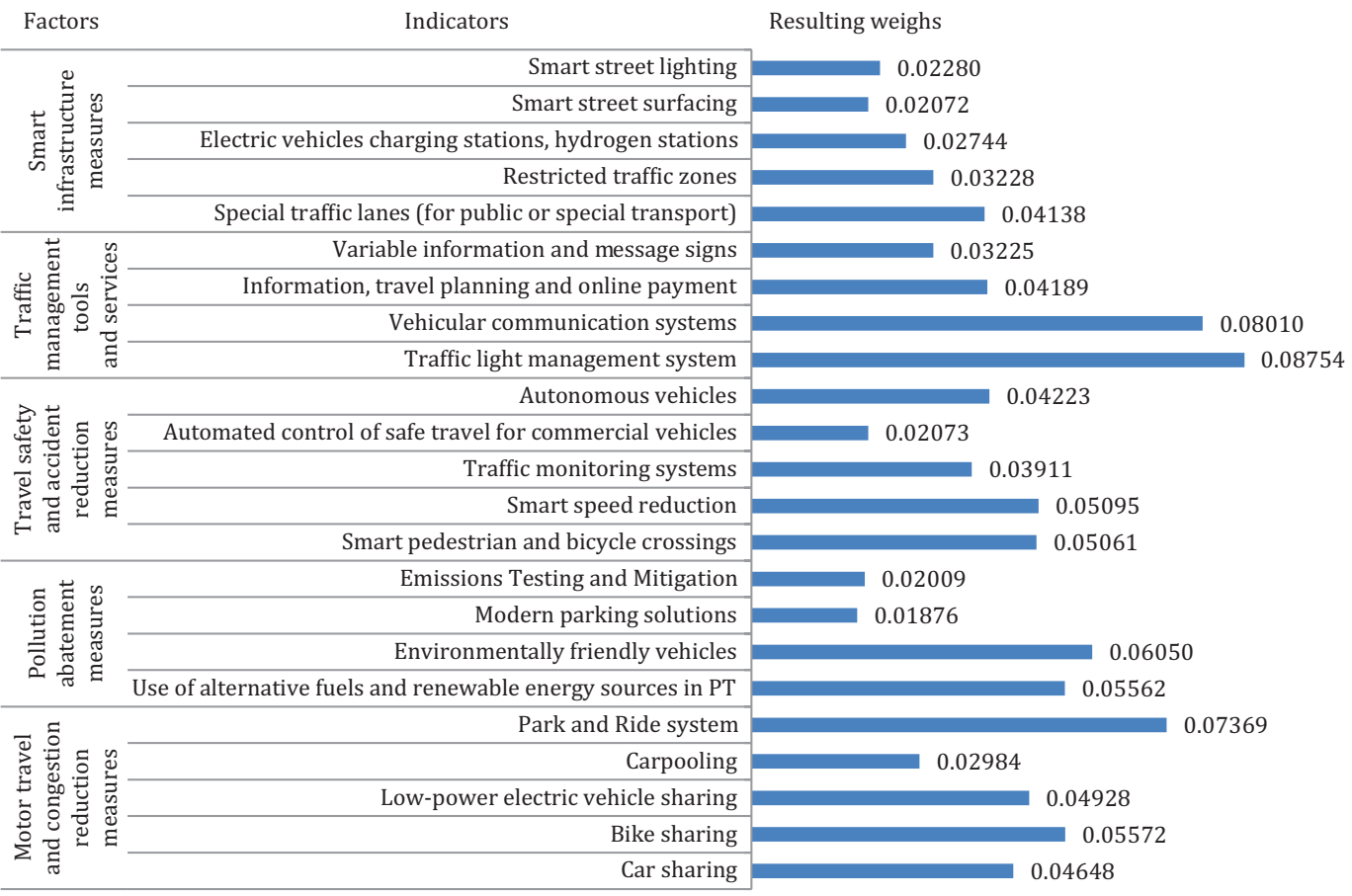

Figure 3. Summarised indicator weights and places by importance 
in the eyes of experts. It is important to reduce the time spent in traffic and have access to various modes of transport. Although the car fleet in Lithuania is relatively old compared to other countries of the European Union, experts believe that it is important to promote introduction of smart technologies, which are necessary for smart vehicles.

The least influence on smart mobility system, according to the experts, is exerted by Modern Parking Solutions (0.01876), Emissions Testing and Mitigation (0.02009) and Smart Street Surfing (0.03072). Smart Infrastructure Measures and Pollution Abatement Measures have the least value. Emissions Testing and Mitigation indicator might be irrelevant for some experts because they would choose different measures to fight pollution in the first place. Modern Parking Solutions and Smart Street Surfing are more expensive to implement compared to other measures. That might be the reason why they seemed to be irrelevant for the experts.

To conclude, more focus is made on the measures aimed to improve the functionality of the transport system than on individual smart technologies. The assessment of factors and indicators may be subjective due to the nature of the expert's work.

\subsection{Analysis of the sensitivity of criteria values}

To solve multi-criteria problems using quantitative multiobjective decision-making methods, deterministic calculations are performed without estimating randomness. Decision makers apply existing models that are strictly mathematically based, regardless of possible inaccuracies in the original data. The resulting solution then does not adequately reflect the real situation and may raise doubts (Simanavičienè \& Ustinovičius, 2011). Results of application of any MCDM method depend on criteria weights to a great extent. Sometimes, the final selection may change when there is a change in the weight coefficients of the criteria (Biswas et al., 2020). In order to ensure that the results obtained are valid and applicable in the real world, it is necessary to perform sensitivity analysis and check the stability of the final results. Changes in the weight values of the criteria are analysed to determine how their significance affects the results. Dynamic sensitivity analysis shows that the change in the priorities of one criterion influences the change in the priorities of other criteria and the priorities of the alternatives within the observed criterion (Stanković et al., 2019).

Sensitivity analysis was performed by comparing the impact of the change in the criterion with the highest weight on the final results. The sensitivity analysis of the weights of the indicators belonging to 


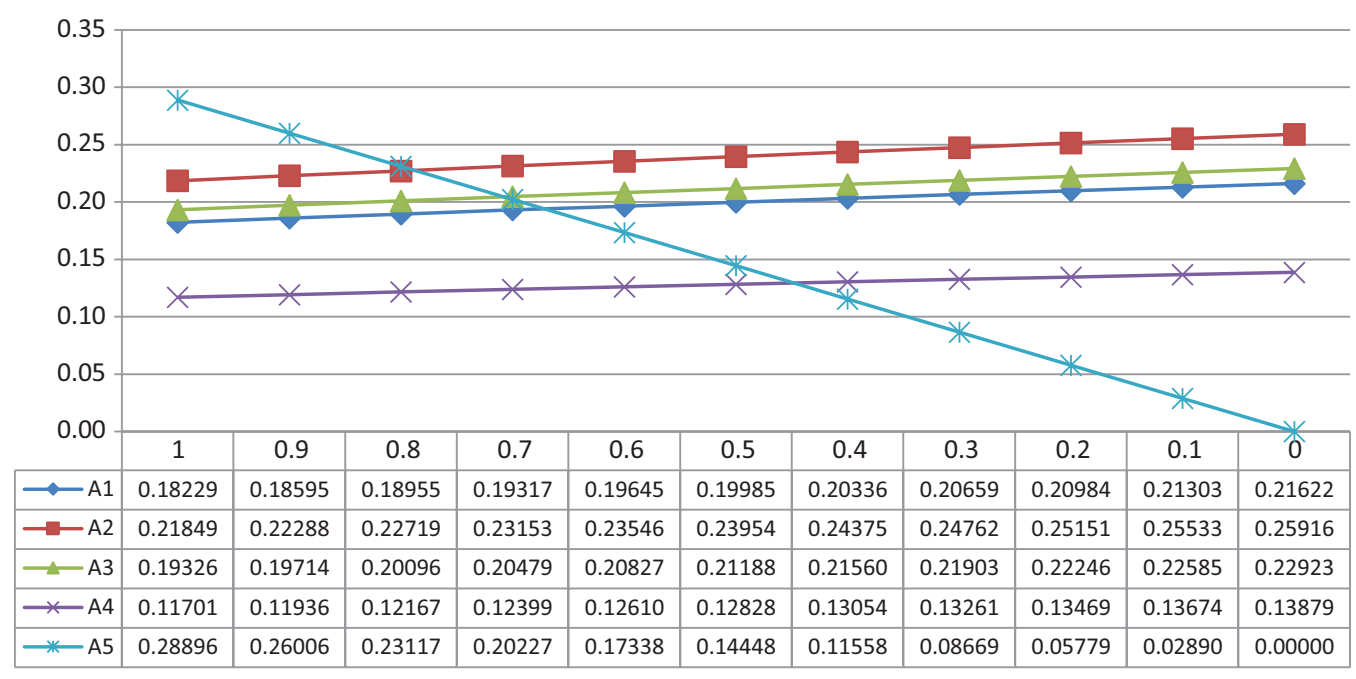

Figure 4. Results of the sensitivity analysis for the factor Motor Travel and Congestion Reduction Measures.

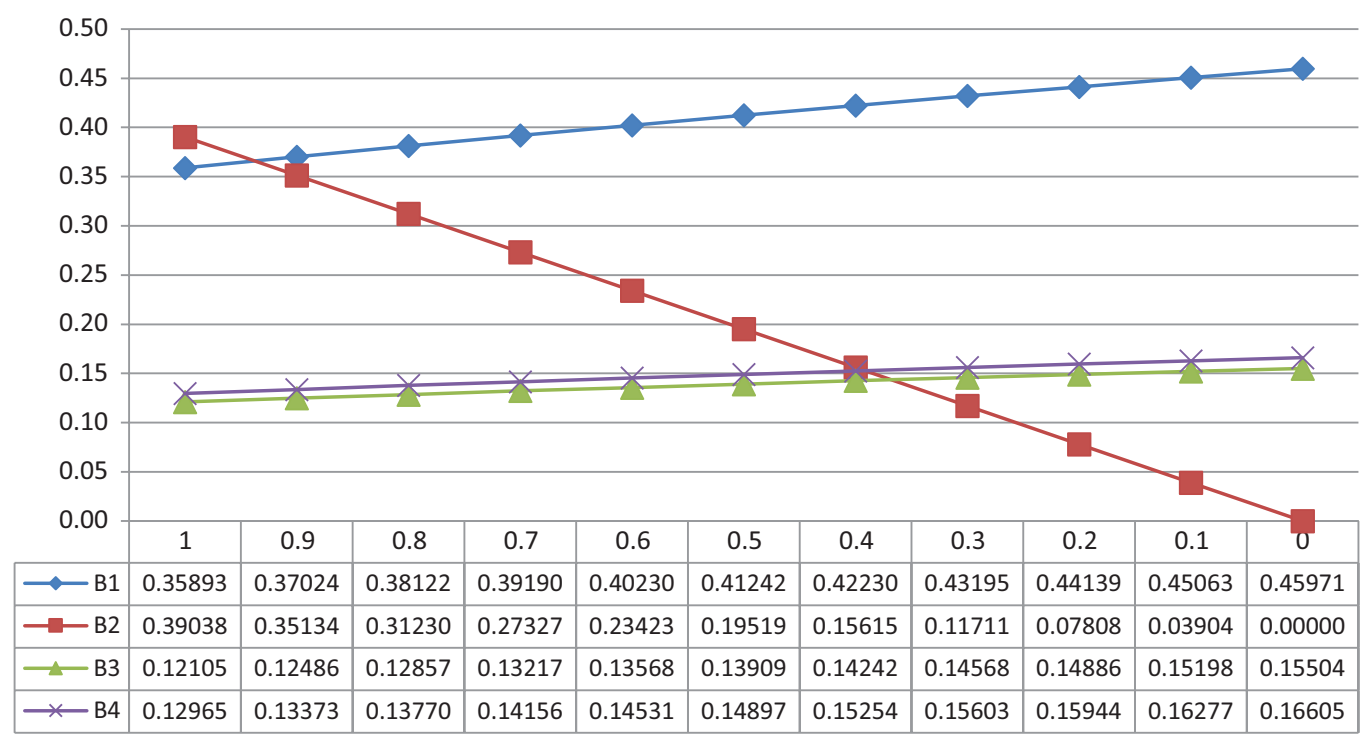

Figure 5. Results of the sensitivity analysis for the factor Motor Travel and Congestion Reduction Measures. 
2020/15(4)

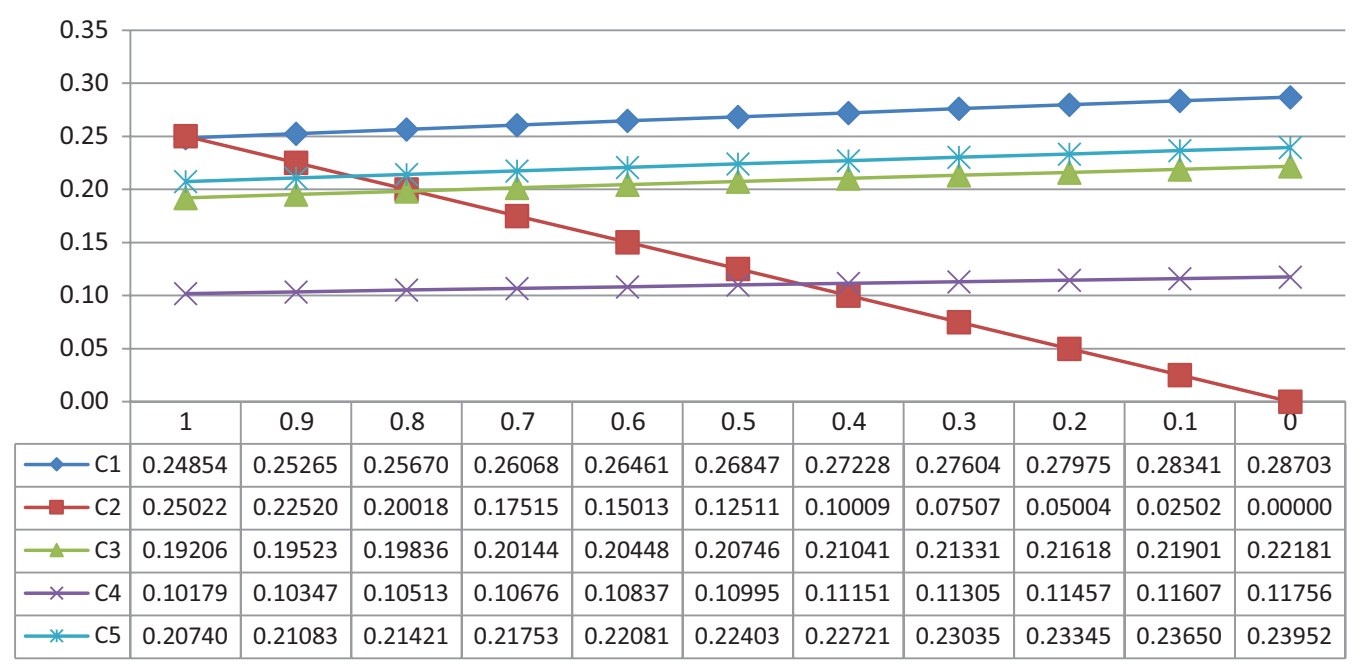

Figure 6. Results of the sensitivity analysis for the factor Travel Safety and Accident Reduction Measures

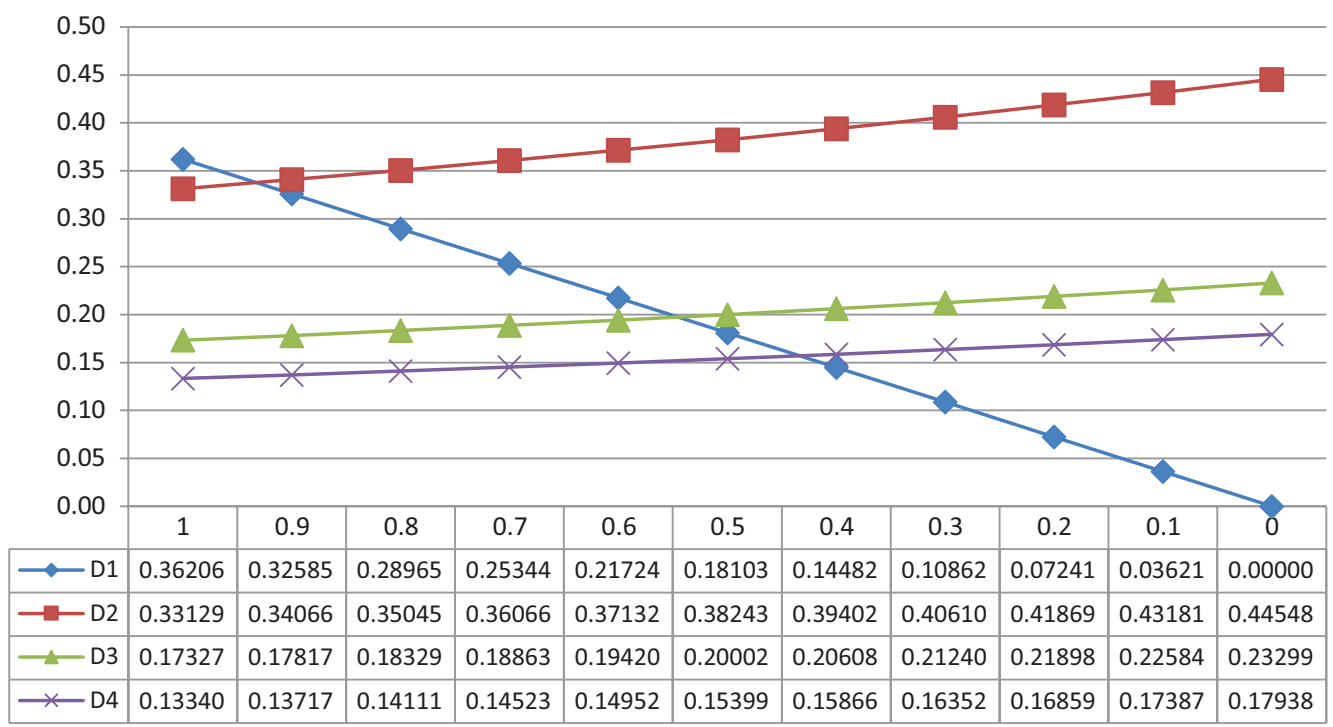

Figure 7. Results of the sensitivity analysis for the factor Traffic Management Tools and Services 
the factor of Motor Travel and Congestion Reduction Measures was Evaluation Criteria of Smart City Mobility System performed in relation to the other indicators of the most significant indicator Park and Ride System (Figure 4).

The dominant value of the Park and Ride System indicator (A5) with the highest weight is 0.8 higher compared to the next weight-based Bike Sharing indicator (A2). The Carpooling (A4) indicator, which has the lowest weight, ranges from 0.45 . This means that a small change in the weight value of the Park and Ride System (10\%) will not affect the changes in the significance of the indicators of this factor.

The sensitivity analysis of the weights of the indicators belonging to the factor Pollution Abatement Measures is presented in Figure 5.

The indicators Environmentally Friendly Vehicles (B2) and Use of Alternative Fuels and Renewable Energy Sources in Public Transport (B1) have a very small difference in weights, therefore the dominance of the indicators changes when the value of indicator B2 decreases by at least $5 \%$. Other indicators of this factor dominate from 0.4 , so a small change in indicator B2 will not affect their importance.

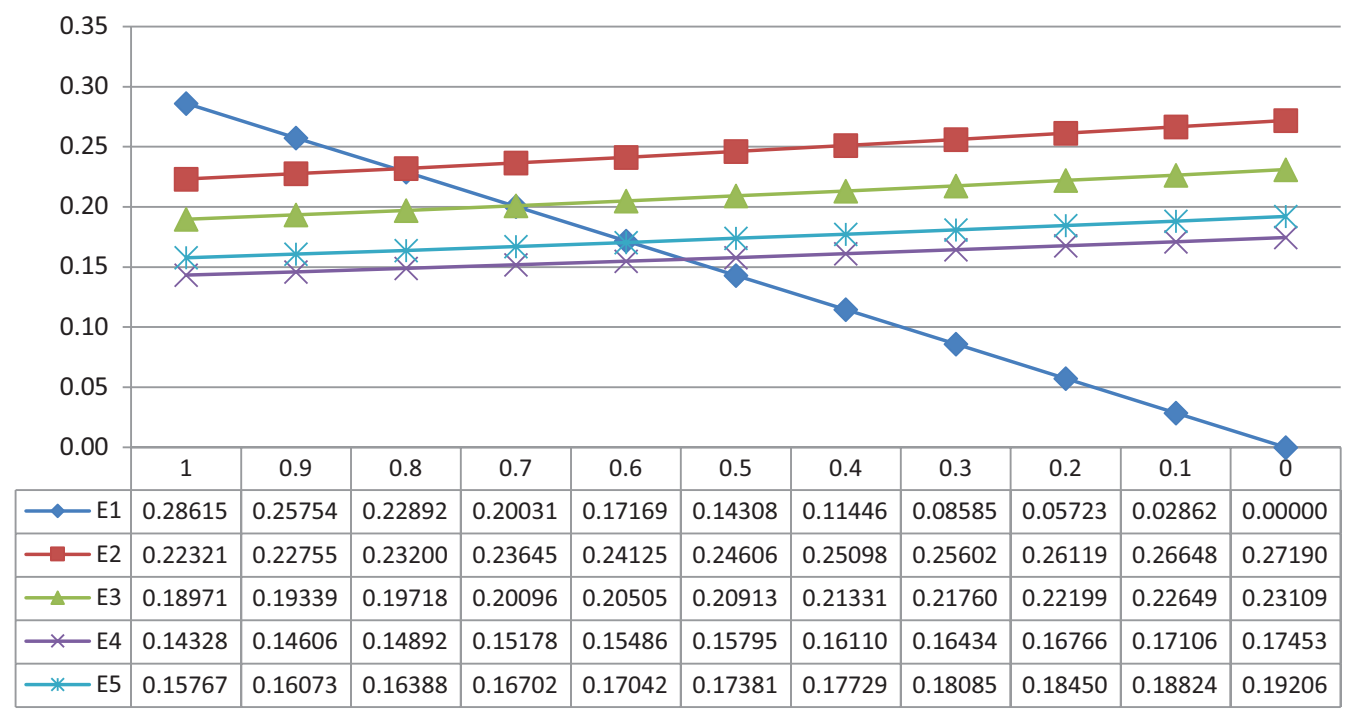

Figure 8. Results of the sensitivity analysis for the factor Smart Infrastructure Measures 
The sensitivity analysis of the weights of the indicators belonging to the factor Travel Safety and Accident Reduction Measures is presented in Figure 6.

The indicators Smart Speed Reduction (C2) and Smart Pedestrian and Bicycle Crossings ( $\mathrm{C} 1$ ) have a very slight difference in weights, so when the value of indicator $\mathrm{C} 2$ decreases by at least $1 \%$, the dominance of the indicators changes. Other indicators of this factor dominate from 0.85 , therefore, a small change in indicator B2 (10\%) will not affect their importance.

The sensitivity analysis of the weights of the indicators belonging to the factor Traffic Management Tools and Services is presented in Figure 7.

The dominant value of the factor Traffic Light Management System (D1) is up to 0.93 . This means that a small change in the value of the indicator Vehicular Communication Systems (D2) (10\%) will not change the significance and dominance of the indicator.

The sensitivity analysis of the weights of the indicators belonging to the factor Smart Infrastructure Measures is presented in Figure 8.

The predominant value of the factor Special Traffic Lanes (for public or special transport) (E1) is up to 0.81 . This means that a small change in the value of the indicator Restricted Traffic Zones (E2) (10\%) will not change the significance and dominance of the indicator.

\section{Conclusions}

This article has presented results of application of comprehensive multicriteria analysis method for comparing smart mobility systems of the cities based on the intelligence of their transport systems considering all evaluation criteria.

Most current mobility assessment practises involve analysis of traffic (movement of vehicles) or mobility (movement of people and goods). They tend to favour road transport over other forms of accessibility, including alternative modes of transport, mobility management and infrastructure.

The results of expert evaluations of the factors and indicators can be applied in practice, provided that there is a sufficient degree of harmonisation among expert opinions. In the expert survey, the concurrence of expert opinions on all factors and indicators (questionnaires) was achieved by interviewing 15 experts.

The next step in this research is to develop an evaluation system and collect indicator data. Later it will be possible to compare mobility systems in the selected cities. 
This evaluation model would enable cities to assess the smartness level of their city mobility systems. This would help cities to see gaps in the implementation of smart systems in their city mobility system and Mobility System Using MCDM to highlight measures that experts consider to be more important in making the city mobility system not only smart but also favourable for the well-being of its citizens.

This evaluation model is quite versatile, so there are no special requirements for cities in order to be compared in terms of their smart mobility system. It is recommended that the cities to be compared are of the same size: large (over 500000 inhabitants) and medium cities (100 000 to 500000 inhabitants), but this is not a prerequisite.

According to the Lithuanian expert survey questionnaires, Traffic Light Management System (controlled and coordinated or adaptive control traffic lights, automatically controlled in response to traffic conditions or upon request of pedestrians) (0.08754), Vehicular Communication Systems (V2X, V2V, V2I technologies, which detect and prevent potential obstacles and alert other road users) (0.08010) and Park and Ride System (0.07369) are the most important indicators of the smart mobility system. The indicators with the least influence on the smart mobility system are Modern Parking Solutions (0.01876), Emissions Testing and Mitigation (0.02009) and Smart Street Surfing (0.03072).

The subjectivity of expert opinions is the limitation of this research. Expert opinion depends on their area of expertise and might depend on their country of domicile, because every country or city has different problems and needs.

\section{REFERENCES}

Albino, V., Berardi, U., \& Dangelico, R. M. (2015). Smart Cities: Definitions, Dimensions, Performance, and Initiatives. Journal of Urban Technology, 22(1), 3-21. http://dx.doi.org/10.1080/10630732.2014.942092

Battarra, R., Gargiulo, C., Tremiterra, M. R., \& Zucaro, F. (2018). Smart Mobility in Italian Metropolitan Cities: A Comparative Analysis Through Indicators and Actions. Sustainable Cities and Society, 41, 556-567.

https://doi.org/10.1016/j.scs.2018.06.006

Benevolo, C., Dameri, R. P., \& D’Auria, B. (2016). Smart Mobility in Smart City. Action Taxonomy, ICT Intensity and Public Benefits. In T. Torre, A. M. Braccini \& R. Spinelli (Eds.), Empowering Organizations. Lecture Notes in Information Systems and Organisation (vol. 11, pp. 13-28). Cham: Springer. https://doi.org/10.1007/978-3-319-23784-8_2 
Bhandari, S. B., \& Nalmpantis, D. (2018). Application of Various Multiple Criteria Analysis Methods for the Evaluation of Rural Road Projects. The Open Transportation Journal, 12, 57-76. https://doi.org/10.2174/1874447801812010057

Biswas, T., Chatterjee, P., \& Choudhuri, B. (2020). Selection of Commercially Available Alternative Passenger Vehicle in Automotive Environment. Operational Research in Engineering Sciences: Theory and Applications, 3(1), 16-27. https://doi.org/10.31181/oresta200113b

Boselli, R., Cesarini, M., Mercorio, F., \& Mezzanzanica, M. (2015). Applying the AHP to Smart Mobility Services: A Case Study. In Proceedings of 4th International Conference on Data Management Technologies and Applications (KomIS-2015). France, Alsace, Colmar.

Broniewicz, E., \& Ogrodnik, K. (2020). Multi-Criteria Analysis of Transport Infrastructure Projects. Transportation Research Part D, 83, 102351. https://doi.org/10.1016/j.trd.2020.102351

Castillo, H., \& Pitfield, D. E. (2010). ELASTIC - A Methodological Framework for Identifying and Selecting Sustainable Transport Indicators. Transportation Research Part D: Transport and Environment, 15(4), 179-188. https://doi.org/10.1016/j.trd.2009.09.002

Debnath, A. K., Chin, H. C., Haque, M. M., \& Yuen, B. (2014). A Methodological Framework for Benchmarking Smart Transport Cities. Cities, 37, 47-56. https://doi.org/10.1016/j.cities.2013.11.004

Deluka-Tibljaš, A., Karleuša, B., \& Dragičević, N. (2013). Review of Multicriteria-Analysis Methods Application in Decision Making About Transport Infrastructure. Građevinar, 65(7), 619-631. https://doi.org/10.14256/JCE.850.2013

Dudzevičiūtè, G., Šimelytė, A., \& Liučvaitienè, A. (2017). The Application of Smart Cities Concept for Citizens of Lithuania and Sweden: Comperative Analysis. Inependent Journal of Management \& Production (IJM\&P), 8(4), 1433-1450. https://doi.org/10.14807/ijmp.v8i4.659

Erdogan, M., \& Kaya, I. (2019). Prioritizing Failures by Using Hybrid Multi Criteria Decision Making Methodology With a Real Case Application. Sustainable Cities and Society, 45, 117-130. https://doi.org/10.1016/j.scs.2018.10.027

Farooq, A., Xie, M., Stoilova, S., \& Ahmad, F. (2019). Multicriteria Evaluation of Transport Plan for High-Speed Rail: An Application to Beijing-Xiongan. Mathematical Problems in Engineering, 2019, 1-23. https://doi.org/10.1155/2019/8319432

Garau, C., Masala, F., \& Pinna, F. (2016). Cagliari and Smart Urban Mobility: Analysis and Comparison. Cities, 56, 35-46. https://doi.org/10.1016/j.cities.2016.02.012

Giffinger, R., Fertner, C., Karmar, H., \& Meijers, L. (2007). Smart Cities Ranking of European Medium-Sized Cities. Final report. Edited by the Centre of Regional Science. Vienna UT. Retrieved from www.smart-cities.eu

Hajduk, S. (2016). The Concept of a Smart City in Urban Management. Business, Management and Education, 14(1), 34-49.

https://doi.org/10.3846/bme.2016.319 
Hall, R. E., Bowerman, B., Braverman, J., Taylor, J., Todosow, H., \& Von Wimmersperg, U. (2000). The Vision of a Smart City. In 2nd International Life Extension Technology Workshop. Paris, 28 September 2000. Retrieved from https://www.researchgate.net/publication/241977644_The_vision_of_a_ smart_city

Kicinski, M., \& Solecka, K. (2018). Application of MCDA/MCDM methods for an integrated urban public transportation system - case study, city of Cracow. Archives of Transport, 46(2), 71-84. https://doi.org/10.5604/01.3001.0012.2107

Krmac, E., \& Djordjević, B. (2019). Evaluation of the TCIS Influence on the Capacity Utilization Using the TOPSIS Method: Case Studies of Serbian and Austrian Railways. Operational Research in Engineering Sciences: Theory and Applications, 2(1), 27-36. https://doi.org/10.31181/oresta1901030k

Litman, T. (2008). Sustainable Transportation Indicators: A Recommended Research Program for Developing Sustainable Transportation Indicators and Data. Sustainable Transportation Indicators Subcommittee of the Transportation Research Board. Retrieved from https://www.vtpi.org/sustain/sti.pdf

Mardani, A., Zavadskas, E. K., Khalifah, Z., Jusoh, A., \& MD Nor, K. (2016). Multiple Criteria Decision-Making Techniques in Transportation Systems: A Systematic Review of the State of the Art Literature. Transport, 31(3), 359-385. https://doi.org/10.3846/16484142.2015.1121517

Marsal-Llacuna, M. L., Colomer-Llina`s. J., \& Mele'ndez-Frigola, J. (2014). Lessons in Urban Monitoring Taken From Sustainable and Livable Cities to Better Address the Smart Cities Initiative. Technological Forecasting and Social Change, 90, 611-622. https://doi.org/10.1016/j.techfore.2014.01.012

Miloševi'c, M. R., Miloševi'c, D. M., Stevi'c, D. M., \& Stanojevi'c, A. D. (2019). Smart City: Modeling Key Indicators in Serbia Using IT2FS. Sustainability, 11(13), 3536. https://doi.org/10.3390/su11133536

Moreira, M. P., Dupont, C. J., \& Vellasco, M. M. B. R. (2009). PROMETHEE and Fuzzy PROMETHEE Multicriteria Methods for Ranking Equipment Failure Modes. In 2009 15th International Conference on Intelligent System Applications to Power. https://doi.org/10.1109/isap.2009.5352823

Orlowski, A., \& Romanowska, P. (2019). Smart Cities Concept: Smart Mobility Indicator. Cybernetics and Systems: An International Journal, 50(2), 118-131. https://doi.org/10.1080/01969722.2019.1565120

Papa, E., \& Lauwers, D. (2015). Smart Mobility: Opportunity or Threat to Innovate Places and Cities. In 20th International Conference on Urban Planning and Regional Development in the Information Society (pp. 534-550). Retrieved from https://conference.corp.at/

Podvezko, V., \& Podviezko, A. (2014). Kriteriju reikšmingumo nustatymo metodai [Methods of estimation of weights]. Lietuvos matematikos rinkinys [Lithuanian mathematics collection], 55, 111-116. https://doi.org/10.15388/LMR.B.2014.21

Podvezko, V., Sivilevicius, H., \& Podviezko, A. (2014). Scientific Applications of the AHP Method in Transport Problems. The Archives of Transport, 29(1), 47-54. https://doi.org/10.5604/08669546.1146966
Evaluation Criteria of Smart City Mobility System Using MCDM Method 
Reiber, L., \& Huang, G. (2018). Comparing Study on Smart City Strategies in Berlin and Shanghai. Advances in Economics, Business and Management Research, 56, 419-422. https://doi.org/10.2991/febm-18.2018.96

Saaty, T. L. (1980). The Analytic Hierarchy Process: Planning, Priority Setting, Resource Allocation. New York: McGraw-Hill. 287 p.

Saaty, T. L. (2008). Decision Making With the Analytic Hierarchy Process. Int. J. Services Sciences, 1(1), 83-98.

Simanavičienė, R., \& Ustinovičius, L. (2011). Daugiatikslių sprendimo prièmimo metodų jautrumo analizè taikant Monte Karlo modeliavimą. Informacijos mokslai, 56, 182-190. https://doi.org/10.15388/Im.2011.0.3138

Sivilevičius, H. (2011). Application of Expert Evaluation Method to Determine the Importance of Operating Asphalt Mixing Plant Quality Criteria and Rank Correlation. The Baltic journal of road and bridge engineering, 6(1), 48-58. https://doi.org/10.3846/bjrbe.2011.07

Stanković, M., Gladović, P., \& Popović, V. (2019). Determining the Importance of the Criteria of Traffic Accessibility Using Fuzzy AHP and Rough AHP Method. Decision Making: Applications in Management and Engineering, 2(1), 86-104. https://doi.org/10.31181/dmame1901086s

Turcksin, L., Bernardini, A., \& Macharis, C. (2011). A Combined AHP-PROMETHEE Approach for Selecting the Most Appropriate Policy Scenario to Stimulate a Clean Vehicle Fleet. Procedia Social and Behavioral Sciences, 20, 954-965. https://doi.org/10.1016/j.sbspro.2011.08.104

Vukovic, N., Rzhavtsev, A., \& Shmyrev, V. (2019). Smart City: The Case Study of Saint-Peterburg 2019. International Review, (1-2), 15-20. https://doi.org/10.5937/intrev1901015v

Wibowo, S., \& Grandhi, S. (2015). A Multicriteria Analysis Approach for Benchmarking Smart Transport Cities. Science and Information Conference. London, UK. https://doi.org/10.1109/sai.2015.7237131

Zhu, S., Lia, D., \& Fengc, H. (2019). Is Smart City Resilient? Evidence From China. Sustainable Cities and Society, 50, 101636.

https://doi.org/10.1016/j.scs.2019.101636 